\title{
Impact of parcel fragmentation on the calculation of the real estate value of land belonging to farms
}

\author{
Manuel Perujo-Villanueva*, Sergio Colombo** \\ DOI: $10.30682 / \mathrm{nm} 2101 \mathrm{~g}$ \\ JEL codes: Q10, Q15, Q18
}

\begin{abstract}
Agricultural parcels are often the subject of land valuation studies. This approach implicitly assumes that the real estate value of the land belonging to a farm is the sum of the values of the individual parcels that make up the farm. Nonetheless, the value of a whole can be very different from the sum of its parts. This study proposes a methodology for calculating the real estate value of the land belonging to a farm, the latter being understood as the set of the parcels, not only on the basis of production factors such as surface area, type of crop and intensity, but also by including parameters relating to the fragmentation of the land. Fragmentation increases production costs and reduces farmers' incomes and by extension the real estate value of the farm. In our study area, the province of Jaen in Spain, figures for its most emblematic crop, the olive, show that fragmentation of the land reduces its value by between $51 \%$ for a 10 ha farm and $12 \%$ for a 30 ha farm as compared to the values set out in the bibliography. The reorganization of the ownership system or the promotion of systems for the common management of land could increase the profitability and therefore the value of land according to the 'income capitalization' approach.
\end{abstract}

Keywords: Farm value, Fragmentation, Income capitalization, GIS.

\section{Introduction}

The object of land valuation is to calculate the price of land on the basis of a series of selected criteria. Agricultural land is valued for a range of purposes, both private (loans, division of estates, mortgages, property sales, agrarian insurance policies, etc.) and public (especially in proceedings such as expropriation, organization of farms, consolidation of farm land, assessment of damage caused by the Administration), and for tax reasons (property tax, tax on the sale or transfer of real estate and documented legal acts, etc.). Accurate calculation of the value of land is therefore vital to guarantee legal certainty for the owner and the protection of his or her rights (López de Luis, 2010). A fair land valuation method is therefore essential.

In the procedure for determining the real estate value of rural land, valuers tend to focus on the values of the individual agricultural parcels that make up the farm (Ma and Swinton, 2012), rather than calculating the real estate value of the farm as a whole. Nonetheless, the value of a whole can be very different from the sum of

\footnotetext{
* IFAPA, Centro Venta del llano, Mengíbar, Jaén, Spain.

** IFAPA, Centro Camino de Purchil, Agroecosost Group, Department of Agricultural Economics, Granada, Spain. Corresponding author: sergio.colombo@juntadeandalucia.es
} 
its parts. A reliable method for calculating the value of the land belonging to a farm as a whole could therefore be particularly important in processes for the wholesale transformation of agrarian structures, in that it would allow much fairer valuations to be made, by taking into account all the factors that influence the real estate value of land. These processes include for example farm reorganization plans, initiatives proposed by government bodies in which grants are provided for the improvement of agrarian structures in areas in which there is a predominance of small and medium-sized holdings in which a land consolidation process is due to be performed (Maceda Rubio, 2014). Farms may also need to be valued when they are put up for sale, often due to a lack of generational renewal (Jeanneaux et al., 2017).

Various methods have traditionally been used to estimate the real estate value of agricultural land (Wahlen et al., 2013) with highly varying results (Jeanneaux et al., 2017). Different methods are used depending on the objective of the valuation, the type of ownership or the particular land use (Wyatt, 1997). One widely used method is the comparative method (Pagourtzi et al., 2003), in which the value is estimated by analysing the sale prices of comparable unimproved land and then adjusting the prices to account for any differences in size, location, and features. However, this method does not take into account the income generated by the property or other important parameters such as soil type, climate and topography. With this in mind, other land valuation methods using regression analysis were developed in order to consider the impact of specific variables such as economic yield, risk of frost, plantation age or land quality (Calatrava and Cañero, 2000; Maddison, 2000). Other researchers also considered the way the farm had been managed when valuing the land (Eves, 2007). Finally, the use of decision tree analysis in the land valuation process was proposed in order to identify possible sub-samples in the available information on rural estate values that represent specific market segments that were not detectable in the original data set (Acciani et al., 2008).

In order to ensure reliable results, these methods generally require significant amounts of information about recent transactions involving similar estates or properties. However, these methods tend not to be used in the valuation of agricultural land in countries like Spain in which there are relatively few rural land transactions and the market is less transparent than for urban and building land (AEBOE, 2015). This is why in those procedures in which the public administration is involved, the use of the 'income capitalization' method has become mandatory. ${ }^{1}$ This method values land on the basis of its suitability for production, in an unlimited scenario which assumes that for the foreseeable future the land will continue to be used for agricultural purposes with the same crop. In this way by calculating the difference between farm revenue and costs, it is possible to calculate the annual return on each parcel being valued. By applying a specific capitalization rate, the real estate value of the land is then obtained.

In order to be able to apply this method correctly, the valuer must know how much income or profit is generated by the lasset he/she is appraising. The most commonly used variable for measuring agrarian income is the area of the land being valued (Cañas et al., 1994; Caballer and Guadalajara, 2005). The analysis of the income from agricultural land also normally involves the valuation of other variables such as economic yield, the quality of the land, the risk of frost and the location (Aznar and Guijarro, 2004; García et al., 2017), which although they influence the profitability of the land are not the only factors affecting it. Other factors that directly affect the profitability of the land and therefore its real estate value are often ignored. For example, Eves (2007) showed that the technical, financial and environmental management of the farm had a direct influence on its value, creating differences in the real estate value of up to $20 \%$.

${ }^{1}$ Royal Decree 1492/2011, of 24th October. Available at: https://www.boe.es/buscar/pdf/2011/BOE-A-201117629-consolidado.pdf. 
Non-monetary values may also add to the value of the farm, as suggested by Howley (2015). In the same way, the fragmentation and dispersion of the parcels of land that make up a farm have a direct impact on its value, in that these farms are often less efficient and produce smaller returns (Latruffe and Piet, 2014; Colombo and Perujo-Villanueva, 2017a; Perujo-Villanueva and Colombo, 2017; Lu et al., 2018). Farms of the same size can have very different costs and therefore profit levels, depending on the number and the shape of the various parcels of land of which they are composed and the distance between them (Tan et al., 2010; Vilar Hernández et al., 2011). These variables often go unnoticed in cost studies used as a reference for calculating the annual income and thus are not considered when estimating the associated real estate value.

In Europe, the extremely fragmented land ownership structure makes it particularly important when valuing land to consider the impact of land fragmentation on farm income. According to EU data, $69 \%$ of farms cover less than 5 ha and only $2 \%$ have more than 100 ha (European Commission, 2013). In this situation any calculation of the profitability of farms, and by extension the real estate value of the land, must take the impact of these variables into account when calculating the differences in income due to the inefficiency of fragmented farms. Small farms have higher costs that reduce their annual income (Colombo and Perujo-Villanueva, 2017a), in some cases even leading to negative returns, which make the 'income capitalization' method inviable.

In this paper we will be focusing on calculating the impact of the structural aspects of farms, namely farm size and parcel fragmentation and dispersion, on the real estate value of the land at farm level, a question that has yet to be broached in the literature. The objective of this research is to create a tool to enable the public administration and land valuers to adjust the real estate value of farms according to the degree of fragmentation, on the basis of simple variables such as the surface area, the number of plots and the distance between them. This is timely considering that in small farms the cost overruns, caused by the lack of economies of scale in production and by land fragmentation, can lead to situations in which it is impossible to break even. It is therefore necessary to encourage the administration to introduce measures to increase the profitability of farms (land consolidation, tax exemptions, farm reorganization plans). For these measures to be successful, accurate valuations of the real estate value of the farms are required. In this research, we also demonstrate that any public or private action aimed at reducing farm fragmentation not only has a positive short-term effect on the economic viability of the farms involved (Vilar Hernández et al., 2010), but also increases their real estate value and in turn the overall wealth of rural communities, a global goal of the Common Agricultural Policy (CAP) today and for the future. The methodology we propose is applied to traditionally farmed olive groves but could also be used with other crops.

The paper is structured as follows: we begin by defining the rules and laws governing the methods used for the valuation of rural property in Spain; we then describe the study area and set out the methodology we propose for quantifying the value of farms. In the results and discussion section we summarize the main effects and comment on the different comparative scenarios for the valuation of rural properties. We conclude by making clear that the real estate value of the farm can vary considerably according to the impact of the spatial distribution and the shape of the parcels. Small atomized farms have much lower values than their larger, more concentrated counterparts.

\section{The valuation of agricultural land in Spain}

In Spain today the Amended Text of the Law on Land and Urban Redevelopment (AEBOE, 2011), hereinafter ATLLUR, provides a general framework for the valuation of land for administrative purposes (Falcón-Pérez, 2015) and advocates the use of the 'income capitalisation' method for calculating the value of agricultural land (Art. 36). This method takes into account the capacity of the land for generating future cash flows and determines income on the basis of the productivity of the estate, focusing particularly on its location, on the type of crop and 
the machinery normally used in its production (Cañero León and Calatrava Requena, 2000), including subsidies of a stable nature and subtracting the costs incurred. The income calculation is based primarily on the consideration of land as a production factor. Specifically, the method is based on calculating the annual income (total revenue minus the costs) and projecting it onto an unlimited scenario based on the useful life of the crop. This means that the value of the agricultural land is affected by the type of crop and by how efficiently it is managed. The final value could be adjusted upwards on the basis of different location factors. In addition, the income capitalisation approach requires the use of an interest rate which, according to the provisions of Additional Clause 7 of the ATLLUR, is determined by a general interest rate multiplied by a corrective coefficient which is published for each type of crop.

The bibliography most critical of this method highlights various aspects: firstly the difficulty of defining the income from each farm, on many occasions resulting in income being calculated as a percentage of final production (Gutiérrez Flores, 2010); secondly the limited availability of cost studies that reflect the real situation of the farm being considered; thirdly, the conditionality involved in using a predetermined interest-rate given that the variability in this rate can have a considerable effect on the real estate value of the property. ${ }^{2}$ Fourthly and finally the fact that sociological factors, which at times are more important than the income from the crop, are not taken into account (Jeanneaux et al., 2017).

None of the studies cited above refer to the need to calculate the value of the farm, defined as the group of parcels that make up the land owned by an olive farmer on which he/ she carries out his/her farming activities, primarily aimed at the market and which constitutes a technical economic unit in itself. In other words, in the aforementioned studies the object being valued is the individual parcel or plot of land and the methodology does not differentiate the case where the farm as a whole is the object of valuation. Farming research has shown that agrarian systems must be considered as a complex fabric and not as a mere collection of agricultural parcels that influence their configuration (De Juan Valero et $a l ., 2003)$ and therefore their production methods and efficiency. In addition, if the management of the different parcels is performed with the same machinery and human resources and within a common agronomic, technical organization, the farm as a whole must be considered as the basic technical unit and not as various basic units, or in other words, various separate farms (Ballestero, 2000).

The Draft version of the Andalusia Agriculture and Livestock Act sets out the case for valuations at farm level. Article 31 of this Act states the need to promote farm reorganization plans in order to create farms of sufficient size and characteristics in terms of their structure, capitalization, business organisation and environmental integration. ${ }^{3}$ This procedure, known as land consolidation, seeks to improve the structure of land ownership in specific districts or areas, for which purposes it is necessary to calculate the value of the set of plots contributed by each farmer, in order to create more concentrated, less fragmented farms with a similar value to that of the land contributed.

\section{Study area}

This research focuses on the traditional, machine-workable (gradients of less than $25 \%$ accessible to tractors) olive groves in the province of Jaen, Southern Spain, which cover $78.5 \%$ of the useful agrarian area. The olive tree is undoubtedly the most emblematic crop in this province, extending over 551,191 ha or $83.3 \%$ of its total farmed area. This represents $26 \%$ of

\footnotetext{
2 The impact of this variability has been attenuated in part by using as the capitalization rate the average value (from the annual data published by the Bank of Spain) for the return on 30-year Government Bonds, for the three years prior to the date to which the valuation is understood to refer (AEBOE, 2015).

3 Draft version of the Andalusia Agriculture and Livestock Act. Available at: https:/www.juntadeandalucia.es/ export/drupaljda/normativa_en_elaboracion/16/10/Texto $\% 20 \mathrm{vesi} \% \mathrm{C} 3 \% \mathrm{~B} 3 \mathrm{n} \% 20 \mathrm{pdf}$.pdf.
} 
the total area planted with olive trees in Spain as a whole and $46 \%$ of the olive groves in Andalusia (CES, 2011). In general terms, the agrarian structure of the province, a concept that includes parameters such as ownership and forms of farming and landholding, is characterized by its heterogeneity and/or polarization: there are a large number of small farms and relatively few large ones. As regards fragmentation, the figures indicate that the average farm has 5.3 ha, although $77.6 \%$ of them have 5 ha or less (Colombo and Perujo-Villanueva, 2017a). The olive farms in the province have a total of 261,450 plots making an average of 3.1 plots per farm. The most fragmented farm has 101 parcels, though farms with more than 10 parcels make up just $3.4 \%$ of the total. As regards the geographical dispersion of the plots, the average value is $4 \mathrm{~km}$. The minimum value is $0 \mathrm{~km}$ for $36 \%$ of the farms and the maximum is $73.6 \mathrm{~km}$ (Perujo-Villanueva and Colombo, 2017). Figure 1 shows a real image of typical olive farm structures in the study area taken from the Spanish Land Parcel Identification System.

Traditional olive farming is showing worrying signs in terms of the return on this crop, especially due to the high fragmentation of ownership, the relatively limited professionalization and modernization of the farms and the high production costs. These low returns mean that many olive farmers depend on subsidies from the CAP and on family labour (Colombo et al., 2016) to break even. The current situation is likely to get worse given the age of the agrarian population in which $74.6 \%$ are over 44 years old and $25.3 \%$ are over 64 years old (CPJA, 2015) and due to the gradual reduction of support from the CAP. The fact that few members of the younger generation seem interested in farming (Langreo Navarro, 2002), the uncertainties of the Common Agricultural Policy and the low income from olive farming combine to paint an unattractive picture for the future of rural Jaen. The result is that a growing number of small

Figure 1 - Examples of the parcel composition and dispersion of typical olive farms in the study area.

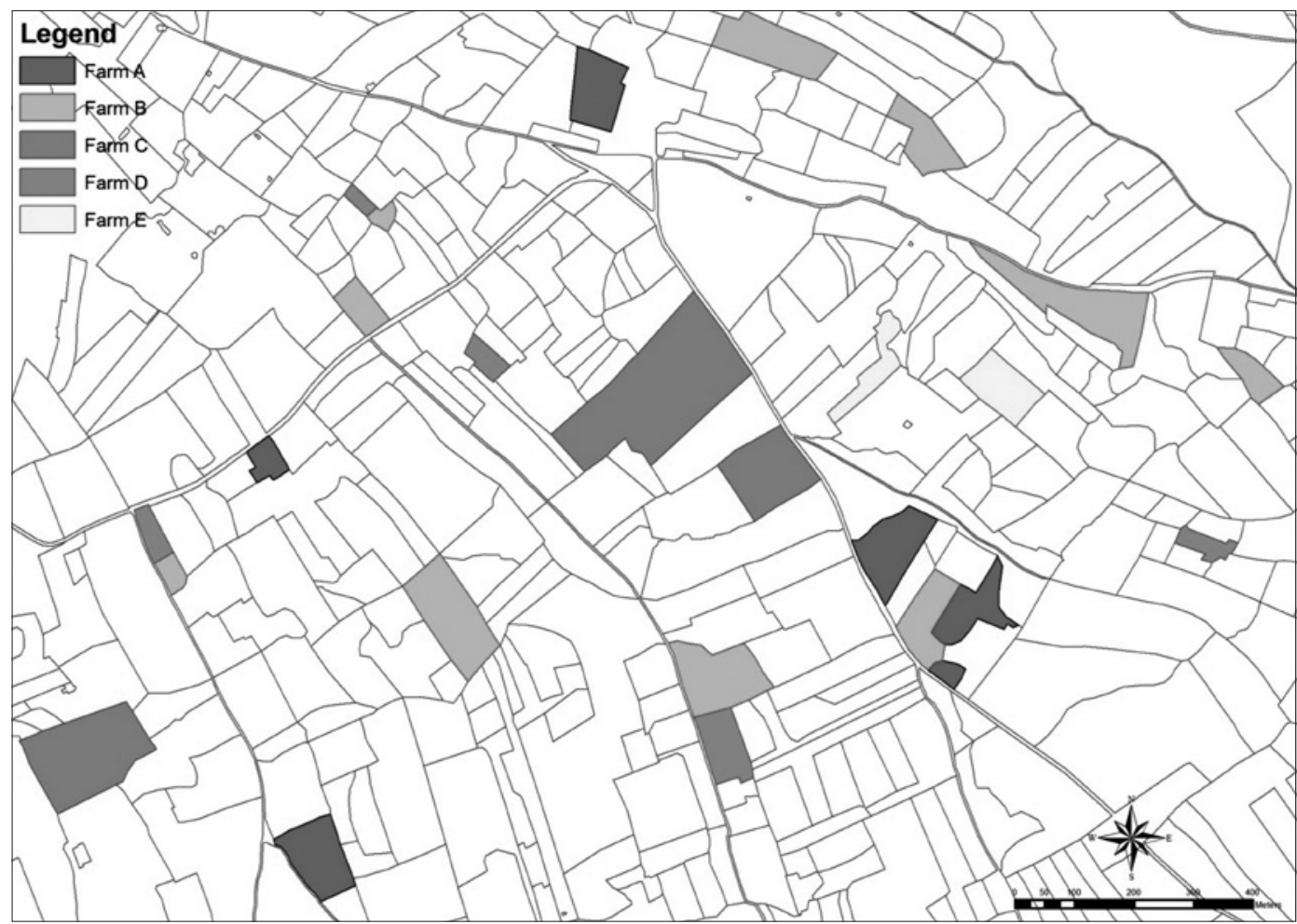


farmers are being forced out of farming every year and their land is being put on the market for sale (Franco and Borras, 2013).

\section{Material and methods}

Using the 'income capitalization' method, the real estate value of the set of agricultural plots belonging to a farm $(J)$ is calculated using the following formula:

$$
\sum_{j}^{J} P V_{j}=\frac{R I P_{1 j}}{\left(1+r_{2}\right)^{1}}+\frac{R I P_{2 j}}{\left(1+r_{2}\right)^{2}}+\ldots+\frac{R I P_{n j}}{\left(1+r_{2}\right)^{n}}
$$

Where $\mathrm{PV}_{\mathrm{j}}$ is the capitalization value of the parcel $j$ (€/ha); $\mathrm{RIP}_{1}, \mathrm{RIP}_{2} \ldots \mathrm{RIP}_{\mathrm{n}}$ is the real or potential annual income ${ }^{4}$ from the parcel $j$, from the first year until the end of the unlimited duration of the useful life $n\left(€ /\right.$ ha); $r_{2}$ is the capitalization rate obtained by multiplying the general capitalization rate $r_{1}$ by the correction coefficient for olive groves of 0.43 , which is specified in Annex 1 of the Land Law Regulations. ${ }^{5}$

With this methodology, it is possible to calculate the value of each parcel and later, assuming that the objective is to calculate the value of a whole farm, add together the values of all the different parcels, on the basis of the profitability per hectare. The profitability figure used for reference purposes is taken from studies carried out by public bodies, from surveys on the price of land (MAPAMA, 2016) and from the Olive Grove Master Plan (CPJA, 2015). However, none of these studies considers the inefficiencies in production due to fragmentation and dispersion or the impact of farm size. For demonstration purposes, the impact of fragmentation and dispersion is highlighted in Figure 2, which shows three farms with the same surface area (1 ha) but different structures. The farm in Square A has no inefficiencies due to fragmentation and dispersion, while those in Squares B and C have excess costs due to these factors, which reduce their income and by extension their real estate value.

In this paper, in order to include the effect of structural factors on farm income we have considered the extra costs resulting from the fragmentation and dispersion of agricultural parcels, so as to subtract it from the total revenue entering the farm. The cost due to fragmentation, which is closely related to the number, shape and size of the parcels, has been calculated according to the methodology described in Colombo and Perujo-Villanueva (2017a). The cost due to dispersion has been estimated using the methodology proposed by Perujo-Villanueva and Colombo (2017). ${ }^{6}$ The general production costs per farm size were obtained using a new software that allows the analyst to enter a wide range of specific data to provide an accurate picture of the production structure of the farm (Colombo et al., 2018; Colombo and Ruz-Carmona, 2019). For these purposes we considered the most likely techniques, management methods and machinery used in the study area. The total production costs are $2547 € /$ ha, $2007 € /$ ha and $1513 € /$ ha for the 1 ha, 10 ha and 30 ha farms respectively.

\footnotetext{
${ }^{4}$ Real income will be understood as that resulting from the farming of rural land according to its state and activity at the time of valuation, be it the duly accredited existing income, or the attributable income according to the particular crops and other farming uses. Potential income will be understood as the income attributable to the farming of rural land in accordance with the most likely uses and activities that are feasible using the normal technical resources for its production.

${ }_{5}$ r1 is calculated according to Royal Decree Law 7/2015, which establishes: " 1 . For the capitalization of the real or potential annual income of a farm, as referred to in Section 1 of Art. 363, the capitalization rate to be used shall be the average value of the annual data published by the Bank of Spain about the profitability of Government Bonds at 30 years, which corresponds to the 3 years prior to the date to which the valuation is understood to refer." At the time of writing this paper the capitalization rate was $2.2 \%$.

${ }^{6}$ Colombo and Perujo Villanueva (2017a) demonstrate that the number and shape of the parcels create inefficiencies in the various tasks involved in olive farming. This leads to an average increase in production costs of between $4.4 \%$ and $6.5 \%$. These costs are higher in farms with small, elongated parcels. In addition, Perujo-Villanueva and Colombo (2017) estimated that the increase in production costs due to parcel dispersion, in other words, the time wasted by the farmer in covering the distance between his/her different parcels is between $1 \%$ and $10 \%$ and is more significant in small farms than in large ones.
} 
Figure 2 - Different fragmentation structures in a typical 1 ha olive farm.

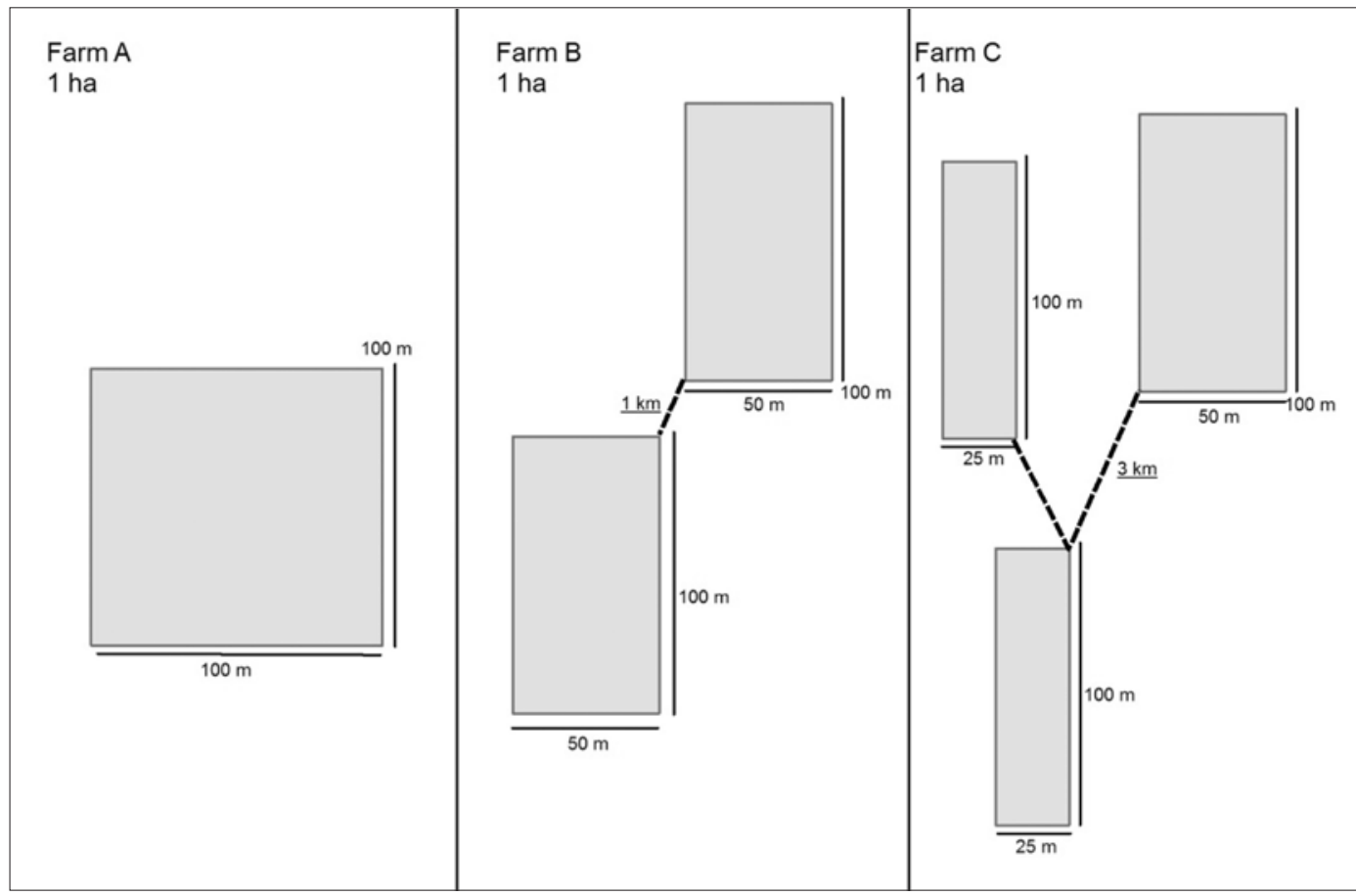

The procedure followed to estimate the production costs are described in papers by Colombo et al. (2016) for farms of between 1 and 10 ha and by Cubero and Penco (2012) for 30 ha farms. In both cases the data obtained refer to rainfed land. Revenues are calculated using average oil price values for the study area and subsidies over the last 10 years. Specifically, we assumed that the average price of olive oil was $2.51 € / \mathrm{kg}$. ${ }^{7} \mathrm{We}$ also assumed a production level of $3500 \mathrm{~kg} / \mathrm{ha}$ and a greasy yield of $21 \%$. The CAP subsidies were $500 € /$ ha. On the basis of these assumptions, the total revenues were $2,345 € /$ ha. The farmer's final income can be calculated by subtracting total production costs from the revenues.

The real estate value of the set of agricultural plots belonging to a farm can be calculated as follows:

$$
\begin{aligned}
F V & =\frac{T R I F_{1}}{\left(1+r_{2}\right)^{1}}+\frac{T_{R I F_{2}}}{\left(1+r_{2}\right)^{2}}+\ldots+\frac{\operatorname{TRIF}_{n}}{\left(1+r_{2}\right)^{n}}= \\
& =\sum_{i=1}^{n \rightarrow \infty} \frac{T R I F_{i}}{\left(1+r_{2}\right)^{i}}
\end{aligned}
$$

$$
T R I F_{n}=\sum_{j}^{J} R I P_{n j}-\left(I F_{n}+I D_{n}\right)
$$

Where FV is the real estate value of the set of agricultural plots that make up a farm; TRIF, is the sum of the income from all the parcels in year $\mathrm{n}$, including the costs resulting from fragmentation and dispersion. IF is the extra cost due to parcel fragmentation and ID is the extra cost due to parcel dispersion.

Clearly, the values for inefficiencies due to fragmentation and dispersion vary from one farm to the next due to their particular spatial structure and dimensions. In this paper the impact of fragmentation and dispersion on real estate value is calculated by applying the average levels of fragmentation and dispersion for all the traditional olive farms in Jaen with more than one parcel, according to the following size ranges: $0.1-1$ ha, 1-5 ha, 5-10 ha, 10-50 ha and over 50 ha. These ranges were chosen because they are the most used in the bibliography for the olive sector. Lastly, given the likely impact

\footnotetext{
${ }^{7}$ This is the weighted average price of extra virgin olive oil, virgin olive oil and lampante oil.
} 
of different capitalization rates on the real estate value of the parcels, we also carried out a sensitivity analysis using capitalization rates of $5 \%$ and $10 \%$.

\section{Results}

The machine-workable traditional olive grove in the province of Jaen covers an area of 448,831 ha. This land is distributed amongst 84,788 farms or smallholdings. The largest olive farm measures 850 ha and the smallest just 0.04 ha. Table 1 shows the number of farms within each size range and the total area they occupy as a percentage of all the land occupied by olive groves.
It is clear that the olive production structure is highly fragmented. In the province of Jaen, the size range with most members is $0.1-1$ hectare (30.1\%) and although $77.6 \%$ of the farms have less than 5 ha, these occupy just $27 \%$ of the total area of olive groves.

The costs resulting from the inefficiencies due to parcel fragmentation and dispersion are described in Table 2. The average inefficiency due to fragmentation for the province of Jaen is $14.7 \%$, which results in an average cost of 100.8 $€ /$ ha, while the average effect of dispersion in production costs is $190.1 € /$ ha. The costs indicated in Table 2 refer to the average costs that the farms incur due to the fragmentation and

Table 1 - Farms by surface area.

\begin{tabular}{|c|c|c|c|c|c|c|}
\hline $\begin{array}{c}\text { Area } \\
\text { (ha) }\end{array}$ & N of farms $^{\text {o }}$ & $\%$ & $\begin{array}{c}\text { Aver. Area } \\
\text { (ha) }\end{array}$ & $\begin{array}{c}\text { Total Area } \\
\text { (ha) }\end{array}$ & $\%$ & Aver. $N^{o}$ Plots \\
\hline $0.1-1$ & 25484 & 30.1 & 0.5 & 15223.5 & $4 \%$ & 1.4 \\
\hline $1.01-2$ & 18515 & 21.8 & 1.4 & 26906.1 & $7 \%$ & 2.3 \\
\hline $2.01-5$ & 21821 & 25.7 & 3.2 & 65380.0 & $16 \%$ & 3.5 \\
\hline $5.01-10$ & 9727 & 11.5 & 6.9 & 60631.4 & $15 \%$ & 5.2 \\
\hline $10.01-50$ & 8074 & 9.5 & 19.5 & 136588.5 & $34 \%$ & 7.4 \\
\hline$>50$ & 1167 & 1.4 & 95.0 & 94339.6 & $24 \%$ & 11.1 \\
\hline
\end{tabular}

Source: The authors - based on SIGPAC 2013.

Characterization of farms on the basis of their size/area and the average number of plots that make them up.

Table 2 - Average cost of parcel fragmentation and dispersion in the province of Jaén (Spain).

\begin{tabular}{|c|c|c|c|c|c|}
\hline $\begin{array}{c}\text { Area } \\
(\mathrm{ha})\end{array}$ & $\begin{array}{c}\text { Inefficiency } \\
\text { due to } \\
\text { fragmentation } \\
(\%)\end{array}$ & $\begin{array}{c}\text { Average } \\
\text { Dispersion } \\
(\mathrm{km})\end{array}$ & $\begin{array}{c}\text { Cost due to } \\
\text { fragmentation } \\
(\boldsymbol{\epsilon} / \mathrm{ha})\end{array}$ & $\begin{array}{c}\text { Cost due to } \\
\text { dispersion } \\
(\epsilon / \mathrm{ha})\end{array}$ & $\begin{array}{c}\text { Total cost } \\
(\epsilon / \mathrm{ha})\end{array}$ \\
\hline $0.1-1$ & 20.1 & 2.6 & 137.1 & 225.1 & 362.2 \\
\hline $1.01-2$ & 16.8 & 4.0 & 114.9 & 227.9 & 342.8 \\
\hline $2.01-5$ & 14.8 & 6.0 & 101.3 & 163.2 & 264.5 \\
\hline $5.01-10$ & 12.6 & 8.5 & 86.5 & 106.6 & 193.0 \\
\hline $10.01-50$ & 9.6 & 10.8 & 66.1 & 70.3 & 136.4 \\
\hline$>50$ & 5.8 & 11.0 & 39.9 & 16.0 & 55.9 \\
\hline
\end{tabular}

Source: The authors - based on SIGPAC 2013.

Determination of the penalization costs (fragmentation and geographic dispersion) according to the size of the farm. 
Figure 3 - Correlation between the area of the farm and the penalization costs. Average values for the different size ranges.

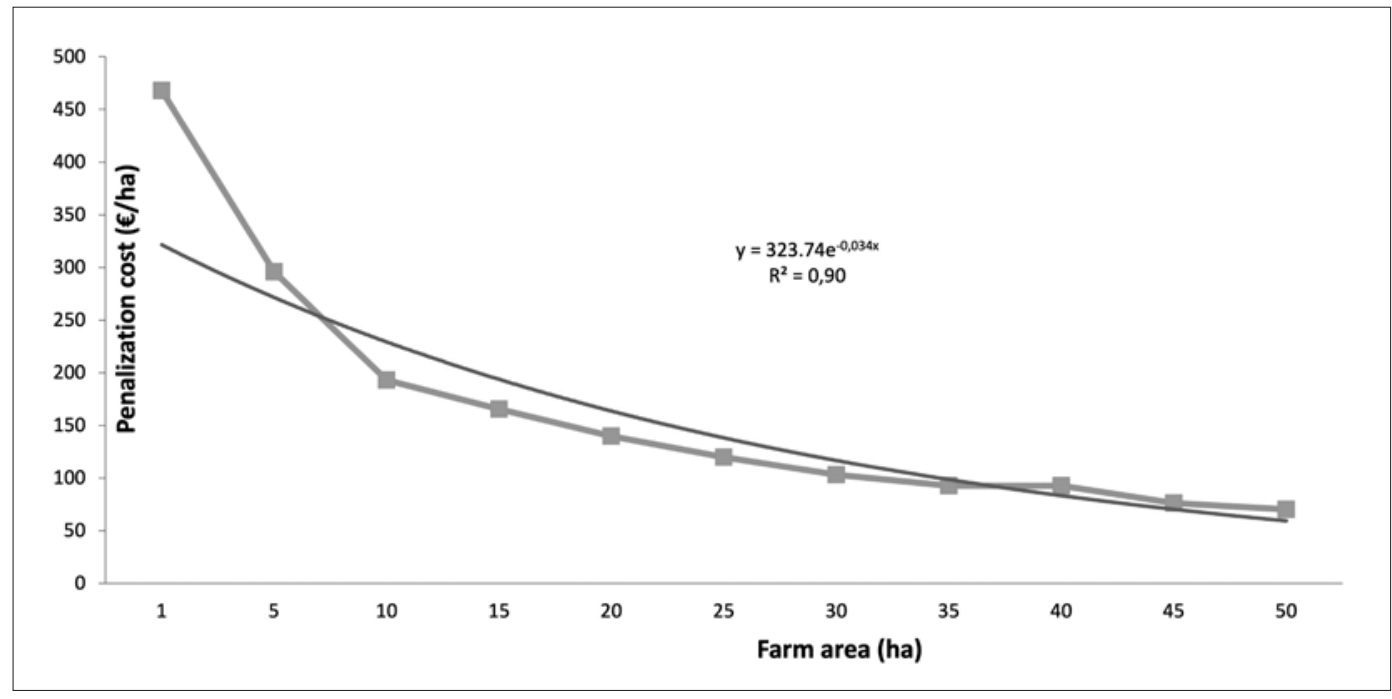

dispersion of the plots. Clearly these costs vary according to the size of the farm, in that larger farms tend to have lower fragmentation and dispersion costs (Colombo and Perujo-Villanueva, 2017a; Perujo-Villanueva and Colombo, 2017). Thus, in order to calculate the real estate value of a farm using Formula 2, it is necessary first to determine the impact of fragmentation and dispersion as a function of farm size. This can be seen in Figure 3, which highlights the relation between farm size and the additional costs incurred due to fragmentation. As can be observed, the two variables have an exponential relationship, illustrating that the impact of fragmentation and dispersion on the profitability of small farms, and thus on their real estate value, is much greater than on medium-sized and large farms, which are much less affected. On average, on 5 ha farms the impact of fragmentation and dispersion causes a fall in income per hectare of 273 euros, whilst on a 30 ha farm this impact is much lower at 117 euros.

If we know the size of the farm, the equation shown in Figure 3 can be used to calculate the general reduction in its income due to fragmentation and dispersion. However, the impact can vary from one farm to the next according to the specific degree of fragmentation and dispersion, given that two farms with the same area can have very different spatial structures. The exact figure for these costs can be established using the methodology proposed by Colombo and Perujo-Villanueva (2017a) and Perujo-Villanueva and Colombo (2017). Detailed information (such as the shape and the geo-referenced location) about each of the parcels that make up the farm is also required. Unfortunately, this information is often unavailable and the calculation process can be too complicated for the valuer interested in determining the impact of fragmentation and dispersion on the income from the farm. A simpler way of assessing this impact would be to use the typical fragmentation and dispersion values for the different farm size ranges. In this paper, this was done by setting a threshold to establish whether fragmentation and dispersion were high or low within each size range. To do that, we used the median number of plots per farm in the case of fragmentation and the median distance between the plots in the case of dispersion for all the farms in the province. Logically, the more intervals we use, the more accurately we can calculate the reduction in the income due to fragmentation and dispersion. For instance, for the $0.1-2$ ha size range, the median fragmentation value was 2 plots and the median dispersion was $2.8 \mathrm{~km}$. That means a farm within this size with 2 plots and a dispersion of 4 $\mathrm{km}$ would be classified as having low fragmentation and high dispersion. When this procedure is 
extended to the whole farm, the valuer can obtain a more accurate estimate of the impact of fragmentation and dispersion on the income of each farm, simply by observing the number of plots and the average distance. The results are shown in Table 3. For farms in the 0.1-2 ha range, with low fragmentation and dispersion, the penalization costs would be $74.4 €$ /ha for fragmentation and $102.4 € /$ ha for dispersion. At the opposite end of the scale, in farms with high fragmentation and dispersion, the additional costs would be as high as $172.3 € /$ ha and $435.4 € /$ ha. In large farms however, these costs were less significant and more homogeneous. For example, for a slightly fragmented farm of over 50 ha, the combined cost of fragmentation and dispersion would be just $30 € /$ ha, while the same farm with high levels of fragmentation and dispersion would have penalization costs of $81.9 € /$ ha.

Table 4 shows the income from and the real estate value of the agricultural plots that make up a typical farm in the study area. The real estate value of the land belonging to a farm was

Table 3 - Penalization costs due to different levels of parcel fragmentation and dispersion by area range.

\begin{tabular}{|l|c|c|c|c|}
\hline \multicolumn{1}{|c|}{$\begin{array}{c}\text { Area } \\
(\mathrm{ha})\end{array}$} & $\begin{array}{c}\text { Low fragmentation } \\
(\epsilon / \mathrm{ha})\end{array}$ & $\begin{array}{c}\text { High fragmentation } \\
(\epsilon / \mathrm{ha})\end{array}$ & $\begin{array}{c}\text { Low Dispersion } \\
(\epsilon / \mathrm{ha})\end{array}$ & $\begin{array}{c}\text { High Dispersion } \\
(\epsilon / \mathrm{ha})\end{array}$ \\
\hline $\begin{array}{l}<2 \\
\left(<=2 \text { plots and } 2.8 \mathrm{~km}^{\mathrm{a}}\right)\end{array}$ & 74.4 & 173.3 & 102.4 & 435.4 \\
\hline $\begin{array}{l}2.1-5 \\
\left(<=3 \text { plots and } 4.1 \mathrm{~km}^{\mathrm{a}}\right)\end{array}$ & 67.5 & 135.7 & 71.6 & 258.6 \\
\hline $\begin{array}{l}5.1-10 \\
\left(<=3 \text { plots and } 5.5 \mathrm{~km}^{\mathrm{a}}\right)\end{array}$ & 57.9 & 114.9 & 47.6 & 167.1 \\
\hline $\begin{array}{l}10.1-50 \\
\left(<=4 \text { plots and } 5.1 \mathrm{~km}^{\mathrm{a}}\right)\end{array}$ & 42.3 & 90.7 & 26.9 & 114.6 \\
\hline $\begin{array}{l}>50 \\
\left(<=5 \text { plots and } 2.0 \mathrm{~km}^{\mathrm{a}}\right)\end{array}$ & 26.2 & 53.7 & 3.8 & 28.2 \\
\hline
\end{tabular}

Source: The authors - based on SIGPAC 2013.

a: Thresholds used to differentiate between low and high fragmentation and dispersion situations.

Penalization costs increase in line with the increase in fragmentation and dispersion. In this table we can see that these costs are higher on smaller farms.

Table 4 - Calculation of the real estate value of the farm according to its size.

\begin{tabular}{|c|c|c|c|c|c|c|c|c|}
\hline $\begin{array}{c}\text { Area } \\
\text { (ha) })\end{array}$ & $\begin{array}{c}\text { Income without } \\
\text { fragmentation and } \\
\text { dispersion costs } \\
(\text { E/ha) }\end{array}$ & $\begin{array}{c}\text { Fragmentation } \\
\text { costs } \\
(€ / h a)\end{array}$ & $\begin{array}{c}\text { Dispersion } \\
\text { costs } \\
(€ / h a)\end{array}$ & $\begin{array}{c}\text { Total } \\
\text { penalization } \\
\text { costs } \\
(€ / h a)\end{array}$ & $\begin{array}{c}\text { Annual } \\
\text { income with } \\
\text { penalization } \\
(€ / h a)\end{array}$ & $\begin{array}{c}\text { Real estate } \\
\text { valueA (rate } \\
2.2 \%) \\
\text { (ha) }\end{array}$ & $\begin{array}{c}\text { Real estate } \\
\text { value (rate 5\%) } \\
\text { (ha) }\end{array}$ & $\begin{array}{c}\text { Real estate } \\
\text { value (rate } \\
10 \%) \\
\text { (ha) }\end{array}$ \\
\hline 1 & -112 & 124 & 276 & 400 & -512 & $\begin{array}{c}-7333 \\
(-33525)\end{array}$ & $\begin{array}{c}-4700 \\
(-21488)\end{array}$ & $\begin{array}{c}-2677 \\
(-12242)\end{array}$ \\
\hline 10 & 338 & 79 & 94 & 173 & 165 & $\begin{array}{c}22132 \\
(10804)\end{array}$ & $\begin{array}{c}14185 \\
(6925)\end{array}$ & $\begin{array}{c}8081 \\
(3945)\end{array}$ \\
\hline 30 & 832 & 56 & 42 & 98 & 734 & $\begin{array}{c}54479 \\
(48062)\end{array}$ & $\begin{array}{c}34918 \\
(30805)\end{array}$ & $\begin{array}{c}19894 \\
(17550)\end{array}$ \\
\hline
\end{tabular}

Source: Present authors based on SIGPAC 2013.

A. The value in brackets includes the penalization due to fragmentation and dispersion costs.

This table shows the real estate values of farms according to their area and estimating the costs of fragmentation and dispersion. 
estimated assuming constant income and the capitalization rate in force at the time the article was written $(2.2 \%)$. The results of a sensitivity analysis using capitalization rates of 5\% and $10 \%$ can also be seen. For 1 ha farms, the income was negative. In farms like these which are barely profitable, the income capitalization approach cannot be used for valuation, given that the real estate value of land cannot be less than zero in any expropriation or land consolidation process. The fact that small olive farms have negative incomes was confirmed by previous researchers (Colombo et al., 2017) who found these farms are only viable thanks to unpaid work by family members. Secondly, for 10 ha farms, the value per hectare of $10,804 €$ was far below the market value, which according to the regional government was between $20,144 €$ and $33,871 €$ (CAPDS, 2018). If the same piece of land were valued without considering the fragmentation parameters, the real estate value would be $22,132 €$, a value more in line with the current market value. The difference between the two valuations was very significant $(51 \%)$, showing the large impact that fragmentation and dispersion can have on farm income. If we analyse the data for 30 ha farms, the real estate value of the agricultural plots that make up the farm would be $48,062 €$, while according to the income capitalization' method, the value would be $54,479 €$, a difference of $12 \%$. Both values are considerably higher than the current market value, so revealing the severe impact that both size and fragmentation and dispersion costs have on farm incomes and thus on the resulting real estate value. The real estate value is also highly dependent on the capitalization rate used in the calculation. As shown in the last two columns of Table 4, if capitalization rates were higher at for example $5 \%$ or $10 \%$, the real estate values would be $36 \%$ and $63 \%$ lower respectively than the value calculated using the currently applicable rate of $2.2 \%$.

\section{Discussion and conclusions}

In Spain the valuation of farmland in public administrative procedures is conducted using the income capitalization method, which values the land according to its capacity to produce revenue. A realistic, accurate valuation is essential from a legal point of view as it has a wide variety of effects in a range of fields such as tax (tax payable), expropriations (for calculating the amount of compensation payable to the owner), mortgages (the land must be valued before a mortgage can be approved) and even for sentence enforcement purposes (judicial sales). The success of the valuation lies in obtaining a value as close as possible to the real market price. The current configuration of the 'income capitalization' method does not provide fair, accurate results especially when valuing farms with more than one plot. For example, a 6-hectare farm made up of 3 two-hectare plots and a dispersion of $15 \mathrm{~km}$ would have the same value as a 6-hectare farm made up of 2 three-hectare farms with just a track running between them. ${ }^{8}$ The market operates in a different way setting higher prices for more concentrated, less fragmented farms.

For a fair valuation of farmland, it is therefore necessary to consider all the costs involved in the management of a farm without forgetting aspects which on certain occasions can create large differences in farm accounts and therefore in the income to be used as the base value. In this paper we have noted the impact that structural variables (such as the size, fragmentation and dispersion of the plots that make up the farm) can have on the real estate value of farmland, especially on small farms. The results show that economies of scale in production not only affect the profitability of the farm but also its real estate value. They also show that this effect is augmented by the fragmentation and dispersion of plots.

The valuation of farmland using the income capitalization approach is also affected by the capitalization rate. This means that the general financial situation, which is an exogenous factor

\footnotetext{
8 The value could change if some of the parcels had different correction factors due to location. However, this seems unlikely with the values established in the valuation rules set out in the Land Act (Ley del Suelo RD 14922011).
} 
of production, may have substantial effects on the price of land, reducing it significantly when the capitalization rate is high.

In order to maintain the real estate value of land it is essential to increase the size of farms and reduce fragmentation into smaller and smaller plots. Various solutions include the reorganization of farms, the concentration of plots and even the implementation of measures that enable farmers to purchase adjacent plots so as to reduce fragmentation. These changes in the land ownership system would make farms more productive, so increasing farming income and by extension the capitalization of agricultural land. Another option would be shared management of the land, either through shared or assisted cultivation (Colombo and Perujo-Villanueva, $2017 \mathrm{~b}$ ). These options increase the income from farming and thus the value of agricultural land. This means that public policies that encourage changes of this kind would also improve the welfare of rural areas.

The information generated during this research could be very useful for the public administration and for the owners of rural land in areas undergoing territorial reorganization processes, especially in places with very fragmented land ownership dominated by smallholdings. On the one hand, considering the role played by structural variables in the formation of income enables a fairer, more equitable valuation of the farmland in areas affected by processes of this kind. This could potentially increase the confidence of farmers in land consolidation procedures, making them more likely to participate (Kupidura et al., 2014). Secondly the reduction in the real estate value of fragmented farms could encourage their owners to reach agreements to join their different plots together, so boosting the market for rural land, which tends to be very static.

The information produced in our research could also be very useful in the design of future laws for the reorganization of farms, such as for example the forthcoming Andalusia Agriculture and Livestock Act. The practical application of future laws must include penalization coefficients due to fragmentation and dispersion in different crops, which must be applied in land valuation processes in which at least two plots belonging to the same owner are involved. In situations in which the public administration is reorganizing the layout and ownership of farmland, the method for valuing the income produces a number of unknowns which must be resolved in the case of crops with a very low or zero rate of return such as traditional olive-farming. In the income capitalization approach, the formula used to calculate the real estate value of the land cannot be applied when the rate of return is zero or negative, and in these cases the real estate value of the land is normally calculated using a pre-established formula, capitalizing a theoretical income equivalent to one third of the minimum income of the land in that particular area. ${ }^{9}$ However, it is important to bear in mind that these agrarian systems provide society with a whole series of non-commercial goods and services (Gómez-Limón and Arriaza Balmón, 2011), which if properly valued would significantly increase their income and by extension their real estate value. For example, from a social point of view, if the impact of self-employment were to be taken into account in the formation of income, we would obtain very different results in our income calculation (Colombo et al., 2016). In this way crops with almost no real estate value from a professional perspective would have some value from a social perspective. Likewise, environmental considerations could be included in the estimation of income from traditional extensive farming after monetising the environmental externalities they originate (Colombo et al., 2006; Villanueva et al., 2014). Recent studies show that in the case of marginal farming systems such as traditional olive-growing, the production of environmental goods could be prioritised to the detriment of commercial products, making the "environmental income" the main income for these systems (Villanueva et al., 2017). These aspects are an excellent basis for future research.

9 Article 16 of the Valuation Regulations from the Land Act (Ley del Suelo RD 1492-2011). 
Future research must also analyze the impact of the subsidy from the Common Agricultural Policy on the income used in the income capitalization method. These subsidies have a huge impact on the profitability of farms and on their real estate value. However, the uneven distribution of subsidies between farms causes large disparities in the valuation of the land regardless of their production capacity. Likewise, the gradual reduction of subsidies from the Common Agricultural Policy has led to a fall in rural wealth without a corresponding reduction in the production capacity.

This research has various limitations which must be considered when interpreting the results. Firstly, the complexity of applying the location factors proposed in the ATLLUR when valuing the land at farm level rather than at parcel level and given that different parcels may have different location factors. One possible solution could be to use the centroid of the farm as the point of reference (Latruffe and Piet, 2014) or to use the average distance from all the plots or from the plot with the largest area, establishing various standardization criteria (Marie, 2009). The impact of different farm location factors on the real estate value of these farms could be an interesting subject for future research.

Another limitation can be observed in concentration, reorganization or expropriation processes that affect some but not all of the plots belonging to the farm. In these cases, the object being valued must be the group of plots affected by the particular procedure and not the whole farm. Finally, we would like to make clear that the maintenance of rural heritage (food safety, environmental protection, supervision and care of rural territories, etc.) is key for the future of Europe. To this end public policies must plan tools that promote a system of agrarian ownership and management that increases the real estate value of farms and by extension the general welfare of rural areas.

\section{Acknowledgments}

This research was co-financed by the Andalusian Institute of Agricultural Economics and Training (IFAPA) project PP.AVA.AVA2019.031 and by the European Regional Development Fund (ERDF).

\section{References}

Acciani C., Fucilli V., Sardaro R., 2008. Model tree: an application in real estate appraisal. Paper presented at 109th EAAE Seminar, 20-21 November, Viterbo.

AEBOE, 2011. Agencia Estatal Boletín Oficial del Estado. Real Decreto 1492/2011, de 24 de octubre, por el que se aprueba el Reglamento de valoraciones de la Ley de Suelo, 270, pp. 116626-116651.

AEBOE, 2015. Agencia Estatal Boletín Oficial del Estado. Real Decreto Legislativo 7/2015, de 30 de octubre, por el que se aprueba el texto refundido de la Ley de Suelo y Rehabilitación Urbana, 261, pp. 1-53.

Aznar J., Guijarro F., 2004. Método de Valoración basado en la Programación por Metas: Modelo de Valoración Restringida. Revista Española de Estudios Agrosociales y Pesqueros, 204: 29-45.

Ballestero E., 2000. Economía de la empresa agraria y alimentaria. Madrid: Mundi-prensa libros.

Boisvert R.N., Schmit T.M., Regmi A., 1997. Spatial, productivity, and environmental determinants of farmland values. American Journal of Agricultural Economics, 79: 1657-1664.

Caballer V., Guadalajara N., 2005. Modelos econométricos de valoración de la tierra de uso agrícola. Una aplicación al Estado Español. Revista Española de Estudios Agrosociales y Pesqueros, 205: 13-38

Calatrava J., Cañero R., 2000. Valoración de fincas olivareras de secano mediante métodos econométricos. Investigación agraria. Producción y protección vegetal, 15: 91-104.

Cañas J.A., Domingo J., Martínez J.A., 1994. Valoración de tierras en las campiñas y la Subética de la provincia de Córdoba por el método de las funciones de distribución. Investigación Agraria. Serie Economía, 9: 447-467.

Cañero León R., Calatrava Requena J., 2000. Valoración de fincas olivareras de secano mediante métodos econométricos. Investigación agraria. Producción y protección vegetales, 15: 91-104.

CAPDS (2018). Precios de la tierra por provincia. Consejería de Agricultura Pesca y Desarrollo Sostenible, Junta de Andalucía. Available at: https:// juntadeandalucia.es/export/drupaljda/TABLA_ PT_2018_PROVISIONAL.pdf.

CES (Consejo Económico y Social de Jaén), 2011. Dictamen sobre el análisis de la rentabilidad económica de las explotaciones de olivar de la provincia de Jaén. España. 
Coelho J., Pinto P.A., Silva L.M., 2001. A systems approach for the estimation of the effects of land consolidation projects (LCPs): a model and its application. Agricultural Systems, 68: 179-195.

Colombo S., Calatrava-Requena J., Hanley N., 2006. Analysing the social benefit of soil conservation measures using stated preferences methods. Ecological Economics, 584: 850-861.

Colombo S., Perujo-Villanueva M., 2017a. The inefficiency and production costs due to parcel fragmentation in olive orchards. New Medit, 16(2): 2-10.

Colombo S., Perujo-Villanueva M., 2017b. Analysis of the spatial relationship between small olive farms to increase their competitiveness through cooperation. Land Use Policy, 63: 226-235.

Colombo S., Perujo-Villanueva M., Ruz-Carmona A., 2016. ¿Tienen futuro las pequeñas explotaciones olivareras tradicionales?. Olimerca, 19: 34-39.

Colombo S., Perujo-Villanueva M, Ruz-Carmona A., 2018. ¿Is bigger better? Evidence from olive-grove farms in Andalusia. Acta Horticulturae, 1199: 165-170.

Colombo S., Ruz Carmona A., 2019. GestOli: un programa para el cálculo de los costes de producción en olivar incluyendo la estructura productiva de las explotaciones. XIX International Scientific Techical Symposium Expoliva, 15-18 May, Jaen.

Colombo S., Sanchez Martinez J.D., Perujo-Villanueva M., 2020. The trade-offs between economic efficiency and job creation in olive grove smallholdings. Land Use Policy, 96, 104696. DOI: doi. org/10.1016/j.landusepol.2020.104696.

CPJA (Consejería de la Presidencia de la Junta de Andalucía), 2015. Decreto 103/2015, de 10 de marzo por el que se aprueba el Plan Director del Olivar. Boletín Oficial de la Junta de Andalucía, 54: 8-154.

Cubero S., Penco J.M., 2012. Aproximación a los Costes del Cultivo del Olivo. Seminario AEMO, Montoro (Córdoba).

Coruhlu Y.E., Yildiz O., 2017. Geographical database for object-oriented land division modelling in Turkey. Land Use Policy, 68: 212-221.

De Juan Valero J.A., Ortega Álvarez J.F., Tarjuelo M.B., 2003. Sistemas de cultivo: evaluación de itinerarios técnicos. Madrid: Mundi-prensa libros.

Delord B., Montaigne E., Coelho A., 2015. Vine planting rights, farm size and economic performance: Do economies of scale matter in the French viticulture sector? Wine Economics and Policy, 4: 22-34.

European Commission, 2013. Structure and dynamics of EU farms: changes, trends and policy relevance. DG Agriculture and Rural Development, Unit Eco- nomic Analysis of EU Agriculture. EU Agricultural Economics Briefs, 9.

European Parliament, 2014. Resolution of 4 February 2014 on the future of small agricultural holdings (2013/2096(INI)). P7_TA(2014)0066. Official Journal of the European Union, 24.3.2017, C 93, 42-46.

Eves C., 2007. Current Rural Valuation Practice: A Survey of Valuers and Agribusiness Managers on Farm Management and Sustainable Rural Land Use. Paper presented at Sustainable Human Settlements for Economic and Social Development Conference, May 2-5, Livingston, Zambia.

Falcón-Pérez C.E., 2015. Método de capitalización de rentas en la valoración del suelo: determinación de las magnitudes económicas. Revista de Derecho Urbanístico y Medio Ambiente, 298: 17-45.

Fernández-Zamudio M.A., De Miguel M.D., 2006. Sustainable management for woody crops in Mediterranean dry-lands. Spanish Journal of Agricultural Research, 4: 111-123.

Franco J., Borras S.M. Jr., 2013. Land Concentration, Land Grabbing and People's Struggles in Europe. Amsterdam, The Netherlands: Transnational Institute. García C., García J., López M.M., Salmerón R., 2017. A generalized method for valuing agricultural farms under uncertainty. Land Use Policy, 65: 121-127.

Gómez-Limón J.A., Arriaza Balmón M., 2011. Evaluación de la sostenibilidad de las explotaciones de olivar en Andalucía. XIII premio Unicaja de Investigación Agraria. Málaga: Ed. Analistas Económicos de Andalucía. Available at: https://www.unicaja.es/resources/1320671483909.pdf.

Gutiérrez Flores M.P., 2010. Valoración de bienes rústicos de utilidad pública: La expropiación forzosa por las obras del AVE en la provincia de León. Pecvnia, 10: 203-229.

Howley P., 2015. The happy farmer: The effect of nonpecuniary benefits on behavior. American Journal of Agricultural Economics, 97(4): 1072-1086.

Jeanneaux P., Desjeux Y., Enjolras G., Latruffe L., 2017. Farm value evaluation: methods and challenges. Paper presented at the 21st IFMA (International Farm Management Association) Congress, 2-7 July, Edinburgh.

Kupidura A., Luczewski M., Home R., Kupidura P., 2014. Public perceptions of rural landscapes in land consolidation procedures in Poland. Land Use Policy, 39: 313-319.

Langreo Navarro A., 2002. La externalización del trabajo agrario y las empresas de servicios a la agricultura. Economía Agraria y Recursos Naturales, 2: 45-67. 
Latruffe L., Piet L., 2014. Does land fragmentation affect farm performance? A case study from Brittany. Agricultural Systems, 129: 68-80.

López de Luis J.R., 2010. Zonas de valor para un modelo unificado de valoración catastral rústica. Revista CT/Catastro, 68.

Lu H., Xiea H., Hea Y., Wua Z., Zhangc X., 2018. Assessing the impacts of land fragmentation and plot size on yields and costs: A translog production model and cost function approach. Agricultural Systems, 161: 81-88.

Ma S., Swinton, S.M., 2012. Hedonic valuation of farmland using sale prices versus appraised values. Land Economics, 88(1): 1-15.

Maceda Rubio A., 2014. De la concentración parcelaria a la ordenación rural. Ería: Revista cuatrimestral de geografía, 93: 5-25.

Maddison D., 2000. A hedonic analysis of agricultural land prices in England and Wales. European Review of Agricultural Economics, 27: 519-532.

MAPAMA, 2016. Ministerio de Agricultura y Pesca, Alimentación y Medio Ambiente. Encuesta de precios de la tierra. Descargable en: http://www.mapama.gob.es/es/estadistica/temas/estadisticasagrarias/economia/encuesta-precios-tierra/.

Marie M., 2009. Des pratiques des agriculteurs à la production de paysage de bocage. Etude comparée des dynamiques et des logiques d'organisation spatiale des systèmes agricoles laitiers en Europe, Basse-Normandie, Galice, Sud de l'Angleterre. Ph-D dissertation of the University of Caen/ Basse-Normandie, Caen (France).

Pagourtzi E., Assimakoupolus V., French N., 2003. Real estate appraisal: a review of different valuation methods. Journal of Property Investment and Finance, 21: 383-401.
Perujo-Villanueva M., Colombo S., 2017. Cost analysis of parcel fragmentation in agriculture: The case of traditional olive cultivation. Biosystem Engineering, 164: 135-146.

Tan S., Heerink N., Kuyvenhoven A., Qu F., 2010. Impact of land fragmentation on rice producers' technical efficiency in South-East China. Wagening Journal of Life Sciences, 57: 117-123.

Vilar Hernández J., Velasco Gámez M., Puentes Poyatos R., 2010. Incidencia del modo de explotación del olivo sobre la renta neta del olivicultor. Estrategias para el cultivo extensivo en el contexto de la posible ausencia de subvenciones. Grasas y Aceites, 61: 430-440.

Vilar Hernández J., Velasco Gámez M., Puentes Poyatos R., Martínez Rodríguez M., 2011. El olivar tradicional: alternativas estratégicas de competitividad. Grasas y Aceites, 62: 221-229.

Villanueva A.J., Gómez Limón J.A., Arriaza M., Rodríguez Entrena M., 2014. Analysing the provision of agricultural public goods; the case of irrigated olive groves in southern. Land Use Policy, 38: 300-313.

Villanueva A.J., Gómez Limón J.A., Rodríguez Entrena M., 2017. Valuation of the supply of public goods by agricultural systems: The case of Andalusian mountain olive groves. Economia Agraria y Recursos Naturales, 17: 25-57.

Wahlen J., Baginski S., Bradshaw M., 2013. Financial Reporting, Financial Statement Analysis, and Valuation: A Strategic Perspective. 8th edition, Boston: Cengage Learning, pp. 1200.

Wyatt P.J., 1997. The development of a GIS-based property information system for real estate valuation. International Journal of Geographical Information Science, 11: 435-450. 